\title{
The method of generating a tractor engine time denisty characteristics
}

\author{
The paper presents a method of generating a time density characteristics - TD of agricultural tractor engines. The \\ principle of operation of the TRS (Tractor Recording System) system and the method of measurement, recording and \\ processing of the measured values have been presented. A TD characteristics of a Z8401.12 engine in a U912 tractor \\ after a year of operation has been described.
}

Key words: agricultural tractor, combustion engine, time density characteristics

\section{Metoda sporządzania charakterystyki gęstości czasowej silników ciągnikowych}

W artykule przedstawiono metodę tworzenia charakterystyki gęstości czasowej TD (Time Density) silników ciagników rolniczych. Przedstawiono zasadę dziatania sytemu TRS (Tractor Recording System) oraz sposób pomiaru, rejestracji i przetwarzania mierzonych wielkości. Opisano charakterystykę TD silnika Z8401.12 po rocznym okresie eksploatacji ciagnika U912.

Słowa kluczowe: ciagnik rolniczy, silnik spalinowy, charakterystyka gętości czasowej

\section{Introduction}

The characteristics of time density constitutes a map of distribution of an engine work time at individual points of communication with the receiver in the area of general engine characteristics, in its particular application. A TD characteristics connects the engine properties with the manner of its operation. Vehicle engines, including agricultural tractors are characterized by a variability of load and engine speed, hence we can assume that their operation is of random nature. A TD characteristics can be identified based on two synchronous courses of the following variables in time [2]:

$$
\begin{aligned}
& \quad \mathrm{n}_{\mathrm{s}}=\mathrm{n}_{\mathrm{s}}(\mathrm{t}) \\
& \text { and } \mathrm{M}_{\mathrm{o}}=\mathrm{M}_{\mathrm{o}}(\mathrm{t}) \\
& \text { for } \mathrm{t} \in\left(0, \mathrm{t}_{\mathrm{e}}\right)
\end{aligned}
$$

where: $n_{s}-$ engine speed $[\mathrm{rpm}], \mathrm{M}_{\mathrm{o}}-$ engine torque $[\mathrm{N} \cdot \mathrm{m}]$, $\mathrm{t}_{\mathrm{e}}$ - time of operation [min].

Engine work field in the coordinate system of $n_{s}-M_{0}$ is divided into rectangular elements of dimensions $\Delta \mathrm{n}_{\mathrm{s}}$ and $\Delta \mathrm{M}_{\mathrm{o}}$ :

$$
\begin{aligned}
\Delta n_{s} & =\frac{n_{s \max }-n_{s \min }}{n} \\
\Delta M_{0} & =\frac{M_{o \max }-M_{o \min }}{M}
\end{aligned}
$$

where: $n, M-$ number of intervals on the axes $n_{s}, M_{o}$.

For the element numbered $(\mathrm{x}, \mathrm{y})$ the time density can be defined:

$$
\operatorname{TD}_{(x, y)}=\frac{t_{(x, y)}}{t_{e}}
$$

where: $t(x, y)$ - time of engine operation in which the quantities $n_{s}$ and $M_{0}$ belong to the field designated as $(x, y)$ [min].

For the making of a TD characteristics of road vehicles, passenger cars in particular, dynamic road tests are applied.

\section{Wstęp}

Charakterystyka gęstości czasowej TD (Time Density) stanowi mapę rozkładu czasu pracy silnika w poszczególnych punktach współpracy z odbiornikiem w obszarze charakterystyki ogólnej silnika, w jego konkretnym zastosowaniu. Charakterystyka TD wiąże właściwości silnika ze sposobem jego eksploatacji. Silniki trakcyjne pojazdów, w tym ciagników rolniczych, cechuje zmienność zarówno obciążenia, jak i prędkości obrotowej wału korbowego, toteż uznać można, że ich eksploatacja ma charakter losowy. Charakterystykę TD zidentyfikować można na podstawie dwóch synchronicznych przebiegów zmiennych w czasie [2] oznaczonych jako (1),

gdzie: $\mathrm{n}_{\mathrm{s}}$ - prędkość obrotowa wału korbowego silnika [obr/min], $\mathrm{M}_{\mathrm{o}}$ - moment obrotowy silnika $[\mathrm{N} \cdot \mathrm{m}], \mathrm{t}_{\mathrm{e}}-\mathrm{czas}$ eksploatacji [min].

Pole pracy silnika w układzie współrzędnych $n_{s}-M_{0}$ dzielone jest na prostokatne elementy o wymiarach $\Delta \mathrm{n}_{\mathrm{s}} \mathrm{i}$ $\Delta \mathrm{M}_{\mathrm{o}}$ określono przez (2) i (3),

gdzie: $n, M-$ liczba przedziałów na osiach $n_{s}, M_{0}$.

Dla elementu o numerach (x,y) gęstość czasową można zdefiniować jako (4),

gdzie: $\mathrm{t}(\mathrm{x}, \mathrm{y})$ - czas pracy silnika, w którym wielkości $\mathrm{n}_{\mathrm{s}} \mathrm{i} \mathrm{M}_{\mathrm{o}}$ należą do pola oznaczonego współrzędnymi (x, y) [min].

Do tworzenia charakterystyki TD silników pojazdów drogowych, szczególnie samochodów osobowych, służą dynamiczne testy jezdne. W warunkach hamowni podwoziowej realizowane są poszczególne sekwencje prędkości i przyspieszeń pojazdu. Zgromadzone w ten sposób dane, w postaci czasów trwania poszczególnych obciążeń silnika w funkcji prędkości obrotowych wału korbowego silnika, pozwalają na odtworzenie stanów pracy, jakie osiaga silnik w warunkach drogowych [1].

Jednak istnieją specyficzne grupy pojazdów, w tym ciągniki rolnicze, dla których niemożliwe jest odzwierciedlenie 
On chassis dynamometers individual speed and acceleration sequences of a vehicle are realized. The data obtained in such a way in the form of times of duration of individual loads in the function of engine speed enable the retrieval of the engines states in the road conditions [1].

There are, however, specific groups of vehicles that include agricultural tractors for which it is impossible to render a pre-set speed distribution as these vehicles are not only used in road transportation but also in non-road applications (constructions, agriculture, stationary drives PTO Power Take Off).

The Making of a TD characteristics for a tractor engine is difficult and time consuming due to the necessity of continuous long term monitoring and recording of work state information in particular conditions of operation. For agricultural tractors such a period should last for at least one agro- technical season. The tractor additionally requires fitting a torque and engine speed recording devices. Yet, such investigations carried out on a representative group of tractors may significantly contribute to the unification of the methods of evaluation of emissions from agricultural tractors.

The manner of measurement of the quantities needed to prepare the TD characteristics, particularly the torque, forces a fitting of a torque meter between the engine crankshaft and the clutch shaft. Due to the compactness of the drive train in a tractor the fitting of such a torque meter is a serious and difficult if not impossible modification of the tractor's drive train [5].

Much simpler in realization are the indirect methods of torque measurement. Several of those are applied in practice. After an appropriate interpretation of the selected indices: exhaust gas temperature, the parameters of the fuel supply system, momentary fuel consumption in the function of engine speed we can calculate the torque at a given moment $[3,4]$.

The estimation of the torque based on the temperature of the exhaust gas gives a large diversity of the results. As the tests show $[3,7]$, the relation of the torque and the temperature of the exhaust gas is largely dependent on the thermal state of the engine as well as the distance of the thermocouple from the exhaust valves. Even though the exhaust gas temperature increment depending on the torque at a steady engine speed is a function similar to a linear one, two engines of the same type may show differences in measurement of the temperature of the exhaust gases due to, for example, different angle of the onset of the fuel injection.

An indirect measurement of the torque based on the fuel supply system parameters gives accurate results in the case of in-line injection pumps. Through a sensor, we can measure and record the displacement of the rack inside a pump that directly renders the angle of rotation of the cylinders in the precision pairs in a pump, thus giving the amount of fuel delivered to the injectors [7].

The simplest method is the indirect measurement of torque based on the momentary fuel consumption [3]. This method requires a flow meter in the fuel delivery system. założonego w teście rozkładu prędkości, gdyż pojazdy te użytkowane są nie tylko w transporcie drogowym, ale także w pracach budowlanych, uprawowych oraz napędach stacjonarnych przez wał odbioru mocy PTO (Power Take Off).

Wykonanie charakterystyki TD silnika ciagnikowego jest trudne i pracochłonne, chociażby ze względu na konieczność ciągłego monitoringu i zapisu informacji o stanie pracy $\mathrm{w}$ dłuższym okresie, w konkretnych warunkach gospodarowania. Dla ciągników rolniczych okres ten powinien wynosić co najmniej jeden sezon agrotechniczny. Ciagnik wymaga ponadto dodatkowego wyposażenia w urządzenia rejestrujące moment i prędkość obrotową wału korbowego silnika. Jednak badania takie, prowadzone na reprezentatywnej grupie ciągników, mogą przyczynić się w znacznym stopniu np. do ujednolicenia metod oceny emisji spalin z ciagnników rolniczych.

Sposób pomiaru wielkości potrzebnych do sporządzenia charakterystyki TD, szczególnie momentu obrotowego, wymusza instalację momentomierza pomiędzy wałem korbowym silnika a wałkiem sprzęgłowym skrzyni przekładniowej. Ze względu na zwartą konstrukcję układu napędowego ciągnika rolniczego, montaż momentomierza powoduje znaczną ingerencję w konstrukcję całego pojazdu, a niekiedy jest niemożliwy [5].

Znacznie łatwiejsze w realizacji są pośrednie metody pomiaru momentu obrotowego. W praktyce eksploatacyjnej stosowanych jest ich kilka. Po właściwej interpretacji wybranych wskaźników, m.in.: temperatury spalin, pozycji regulacyjnych urządzeń zasilających, chwilowego zużycie paliwa, w funkcji prędkości obrotowej wału korbowego silnika, możliwe jest obliczenie wartości momentu obrotowego jaki rozwija on w danej chwili $[3,4]$.

Szacowanie momentu obrotowego na podstawie temperatury spalin daje dużą rozbieżność wyników. Jak wykazują badania [3, 7], zależność momentu obrotowego od temperatury spalin w znacznym stopniu uwarunkowana jest stanem cieplnym silnika oraz odległością umieszczenia termopary pomiarowej od zaworów wylotowych. Wprawdzie przyrost temperatury spalin w zależności od momentu obrotowego, przy stałej prędkości obrotowej wału korbowego silnika, jest funkcją zbliżoną do liniowej, to jednak dwa silniki tego samego typu mogą wykazywać różnice w pomiarze temperatury spalin, wynikające chociażby z różnych ustawień kąta początku tłoczenia paliwa.

Pośredni pomiar momentu obrotowego na podstawie pozycji regulacyjnych urządzeń zasilających daje wystarczająco dokładne rezultaty w przypadku rzędowych pomp wtryskowych. W prosty sposób można mierzyć i rejestrować za pośrednictwem czujnika przesunięcie listwy zębatej pompy, która bezpośrednio odwzorowuje kąt obrotu tłoczków par precyzyjnych pompy wtryskowej, a więc i dawkę paliwa tłoczonego do wtryskiwaczy [7].

Jednak najłatwiejszy w praktycznej realizacji jest pośredni pomiar momentu obrotowego na podstawie chwilowego zużycia paliwa [3]. Metoda ta wymaga jedynie instalacji przepływomierza w układzie zasilania paliwem. Dokładność pomiaru momentu uzależniona jest w tym przypadku 
The accuracy of the measurement is in this case reliant on the accuracy of the flow meter. The conversion of the supplied fuel into the number of engine revolutions enables to eliminate the error of variable general efficiency in the whole area of engine operation. The aim of the investigation was to develop a method of preparation of a TD characteristics for engines applied in agricultural tractors. The investigation continued for the period of one year on a Z8401.12 engine fitted in a U912 tractor unit.

\section{Methodology}

In the Chair of Basics of Technology at University School of Agriculture in Szczecin a prototype of a TRS (Tractor Recording System) system has been developed for the preparation of TD characteristics of a piston combustion engine [6]. The recording device, presented in Fig. 1 consists of the following measurement systems:

a) Engine speed,

b) Hourly fuel consumption rate,

c) Vehicle geographical location,

d) Microprocessor module with external memory.

Through the TRS system we can read and store the following information about the engine state:

a) Start and stop time of the engine,

b) Engine work time,

c) Engine speed,

d) Hourly fuel consumption rate,

e) Tractor's geographical location.

Aside from the recording of the directly measured quantities we can also calculate and store the following quantities by introducing appropriate algorithms:

a) Distance covered,

b) Trajectory,

c) Linear velocity,

d) Linear acceleration or deceleration,

e) Engine torque,

f) Power output.

The value of the torque necessary for the preparation of the TD characteristics can be indirectly obtained through:

$$
\mathrm{M}_{\mathrm{o}}=\mathrm{a} \cdot \mathrm{g}_{1000}^{3}+\mathrm{b} \cdot \mathrm{g}_{1000}^{2}+\mathrm{c} \cdot \mathrm{g}_{1000}+\mathrm{d}
$$

where quantity $g_{1000}$ is described by the equation:

$$
\mathrm{g}_{1000}=\frac{\dot{\mathrm{V}}_{\mathrm{pal}}}{\mathrm{n}_{\mathrm{s}}} \cdot 10^{3}
$$

głównie od dokładności miernika przepływu paliwa. Przeliczenie zużytego podczas pomiaru paliwa na stałą liczbę obrotów wału korbowego silnika pozwala jednocześnie na wyeliminowanie błędu wynikającego z różnej sprawności ogólnej w całym obszarze pracy silnika. Celem badań było opracowanie metody tworzenia charakterystyki TD silników stosowanych w ciaggnikach rolniczych. Badania wykonano w okresie jednego roku, na silniku Z8401.12, w który wyposażony jest ciagnik U912.

\section{Metodyka badań}

W Zakładzie Podstaw Techniki Akademii Rolniczej w Szczecinie opracowano i wykonano prototyp systemu TRS (Tractor Recording System) do sporządzania charakterystyki TD tłokowego silnika spalinowego [6]. Przedstawione na rys. 1 urządzenie pomiarowo-rejestrujące TRS złożone jest z układu do pomiaru:

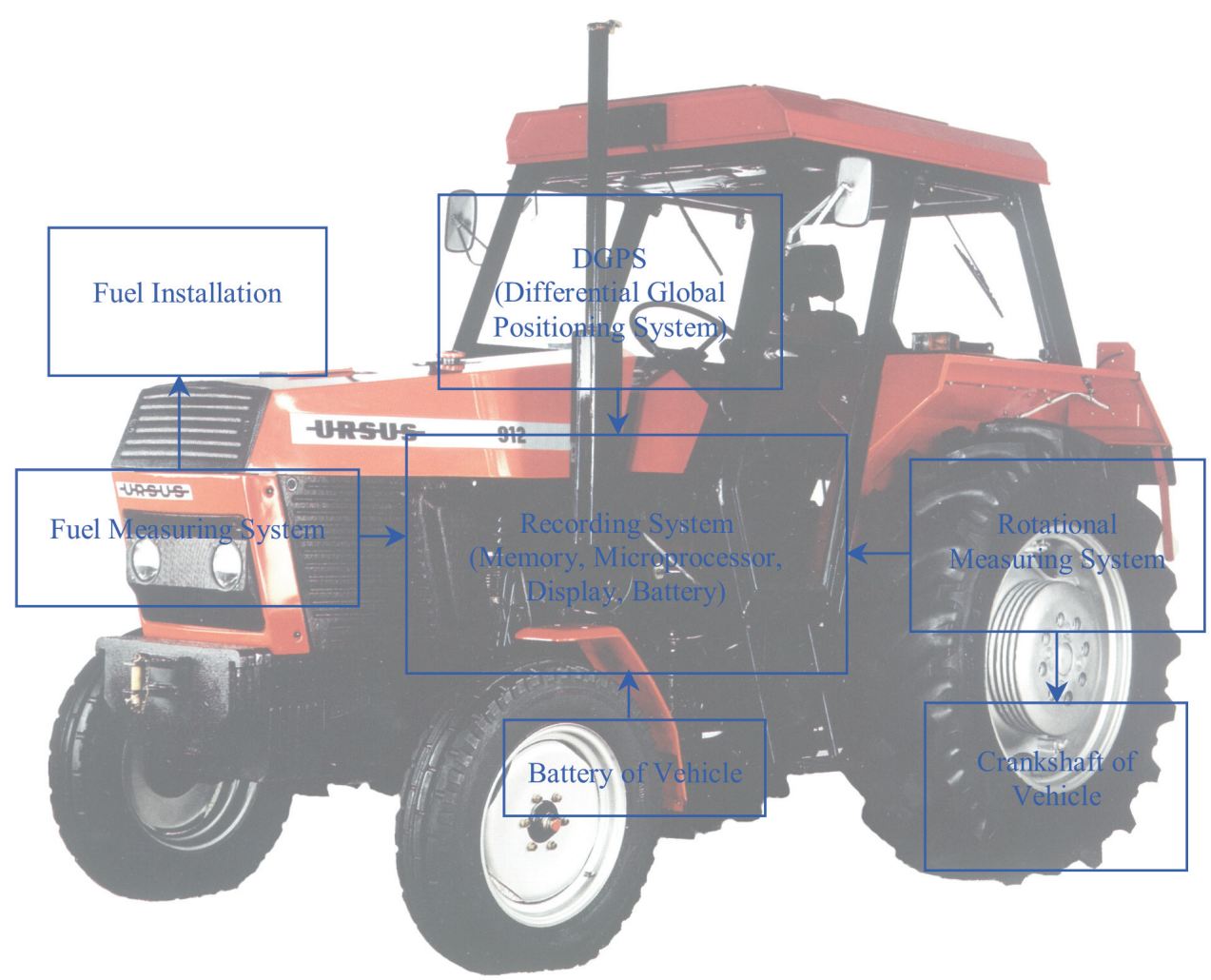

Fig. 1. Schematics of TRS fitted in U912

Rys. 1. Schemat systemu TRS zainstalowanego na ciagniku U912

a) prędkości obrotowej wału korbowego silnika,

b) godzinowego zużycia paliwa,

c) położenia geograficznego pojazdu,

d) modułu rejestratora $\mathrm{z}$ mikroprocesorem i pamięcią zewnętrzną.

Za pomocą systemu TRS można odczytywać i gromadzić w pamięci zewnętrznej następujące dane o stanie pracy ciagnika:

a) godzinę uruchomienia i zatrzymania silnika pojazdu,

b) czas pracy silnika, 
where: a, b c c d-coefficients characteristic for a given engine, $\mathrm{g}_{1000}$ - fuel consumption per 1000 revolutions [ $\left.\mathrm{dm}^{3} / 1000 \mathrm{rpm}\right]$, $\dot{\mathrm{V}}_{\text {pal }}-$ volumetric fuel flow intensity $\left[\mathrm{dm}^{3} / \mathrm{min}\right], \mathrm{n}_{\mathrm{s}}-$ engine speed [rpm].

The coefficients a, b, c, d can be calculated as per the sequence of mathematical operations below. The basis for the calculations is the system of equations:

$$
\left\{\begin{array}{l}
\mathrm{N}_{\mathrm{e}}=\frac{\mathrm{M}_{\mathrm{o}} \cdot 2 \cdot \Pi \cdot \mathrm{n}_{\mathrm{s}}}{60 \cdot 10^{3}} \\
\mathrm{~g}_{\mathrm{e}}=\frac{\mathrm{G}_{\mathrm{e}}}{\mathrm{N}_{\mathrm{e}}} \cdot 10^{3}
\end{array}\right.
$$

where: $\mathrm{N}_{\mathrm{e}}$ - nominal power output $[\mathrm{kW}], \mathrm{g}_{\mathrm{e}}-$ specific fuel consumption $[\mathrm{g} /(\mathrm{kW} \cdot \mathrm{h})], \mathrm{G}_{\mathrm{e}}$ - hourly fuel consumption $[\mathrm{kg} / \mathrm{h}]$,

whose solution is the relation:

$$
\mathrm{G}_{\mathrm{e}}=\frac{\mathrm{M}_{\mathrm{o}} \cdot 2 \cdot \Pi \cdot \mathrm{n}_{\mathrm{s}} \cdot \mathrm{g}_{\mathrm{e}}}{60 \cdot 10^{6}}
$$

Assuming that the measurement of the fuel consumption in the field is possible through the volumetric method we can note:

$$
\mathrm{G}_{\mathrm{e}}=60 \cdot \dot{\mathrm{V}}_{\mathrm{pal}} \cdot \rho_{\mathrm{pal}}
$$

where: $\rho_{\text {pal }}-$ fuel density $\left[\mathrm{kg} / \mathrm{dm}^{3}\right]$.

After substituting (9) to relation (8) and conversion we obtain:

$$
\dot{\mathrm{V}}_{\mathrm{pal}}=\frac{\mathrm{M}_{\mathrm{o}} \cdot 2 \cdot \Pi \cdot \mathrm{n}_{\mathrm{s}} \cdot \mathrm{g}_{\mathrm{e}}}{3600 \cdot 10^{6} \cdot \rho_{\mathrm{pal}}}
$$

Then, after substituting the equation (6) to the equation (10) we obtain the ultimate relation:

$$
\mathrm{g}_{1000}=\frac{2 \cdot \Pi \cdot \mathbf{M}_{\mathrm{o}} \cdot \mathrm{g}_{\mathrm{e}}}{3600 \cdot 10^{3} \cdot \rho_{\mathrm{pal}}}
$$

Based on the general characteristics of a given engine type we need to convert the values of unitary fuel consumption into quantity $\mathrm{g}_{1000}$ as per relation (11). For each engine speed we obtain a sequence of numbers that forms a multinomial function. We can also assume the same values of coefficients for all the values of engine speeds but in such a case the calculation error in the extreme fields of universal characteristics may reach several per cent.

The determined values of coefficients $a, b$, $\mathrm{c}, \mathrm{d}$ for the engine speed ranges of Z8401.12 have been presented in Table 1.

In the developed method of the preparation of a TD characteristics the measured quantities are calculated and recorded in constant time intervals. Subsequently, these quantities are averaged for each time interval. This method is more accurate as opposed to the method of momentary quantity sampling. The measurements of the momentary quantities such as fuel flow require devices of high measurement accuracy which renders them more expensive. c) prędkość obrotową wału korbowego silnika,

d) godzinowe zużycie paliwa przez silnik,

e) położenie ciagnika według danych geograficznych.

Oprócz zapisu bezpośrednio zmierzonych wielkości można także, przez wprowadzenie do pamięci modułu rejestratora odpowiednich algorytmów, obliczyć i zapisać wielkości:

a) długość przebytej drogi,

b) trajektorię ruchu,

c) prędkość liniowa,

d) przyspieszenie lub opóźnienie w ruchu liniowym,

e) rozwijany moment obrotowy silnika,

f) rozwijaną moc.

Niezbędny do stworzenia charakterystyki TD moment obrotowy można obliczyć metodą pośrednią wg zależności (5), w której wielkość $\mathrm{g}_{1000}$ jest opisana równaniem (6), gdzie: a, b, c, d - współczynniki charakterystyczne dla danego typu silnika, $g_{1000}$ - zużycie paliwa na 1000 obrotów wału korbowego silnika [ $\left.\mathrm{dm}^{3} / 1000 \mathrm{obr}\right], \dot{\mathrm{V}}_{\text {pal }}$-objętościowe natężenie przepływu paliwa $\left[\mathrm{dm}^{3} / \mathrm{min}\right], \mathrm{n}_{\mathrm{s}}$ - prędkość obrotowa wału korbowego silnika [obr/min].

Współczynniki a, b, c, d można wyznaczyć według poniższego toku działań matematycznych. Podstawą obliczeń jest układ równań (7),

gdzie: $\mathrm{N}_{\mathrm{e}}$ - moc znamionowa [kW], $\mathrm{g}_{\mathrm{e}}$ - jednostkowe zużycie paliwa $[\mathrm{g} /(\mathrm{kW} \cdot \mathrm{h})], \mathrm{G}_{\mathrm{e}}$ - godzinowe zużycie paliwa $[\mathrm{kg} / \mathrm{h}]$, którego rozwiązanie stanowi zależność (8).

Zakładając, że pomiar ilości zużywanego paliwa w warunkach polowych jest możliwy wyłącznie metodą objętościową, można zapisać (9),

gdzie: $\rho_{\text {pal }}$ - gęstość paliwa $\left[\mathrm{kg} / \mathrm{dm}^{3}\right]$.

Po podstawieniu (9) do zależności (8) i przekształceniu otrzymano (10).

Następnie, po podstawieniu równania (6) do równania (10) otrzymano ostateczną zależność (11).

Na charakterystyce ogólnej danego typu silnika należy przeliczyć wartości jednostkowego zużycia paliwa na wielkość $g_{1000}$ wg zależności (11). Powstaje wtedy, dla każdej prędkości obrotowej wału korbowego silnika, uszeregowany ciąg liczb tworzący funkcję wielomianową. Można również przyjąć te same wartości współczynników dla wszystkich wartości prędkości obrotowych, wtedy jednak błąd obliczeń

Table 1. Values of coefficients a, b, c, d (eq. 5), characteristic of Z8401.12

Tabela 1. Wartości wspótczynników a, b, c, d we wzorze (5), charakterystyczne dla silnika Z8401.12

\begin{tabular}{|c|c|c|c|c|}
\hline $\begin{array}{l}\text { Engine speed } \mathrm{n}_{\mathrm{s}}[\mathrm{rpm}] / \text { Prędkość obroto- } \\
\text { wa watu korbowego silnika [obr/min] }\end{array}$ & \multicolumn{5}{|c|}{ Coefficients/ Współczynniki } \\
\hline & $\mathrm{a}$ & $\mathrm{b}$ & $\mathrm{c}$ & $\mathrm{d}$ \\
\hline under/poniżej 550 & $2 \cdot 10^{-5}$ & 0.0113 & 0.7329 & 5.3038 \\
\hline $550-850$ & $-2 \cdot 10^{-5}$ & 0.0111 & 0.7375 & 5.3835 \\
\hline $850-1150$ & $3 \cdot 10^{-5}$ & 0.0031 & 1.0981 & 1.8143 \\
\hline $1150-1450$ & $1 \cdot 10^{-5}$ & 0.0081 & 0.8222 & 5.2349 \\
\hline $1450-1750$ & $-7 \cdot 10^{-5}$ & 0.0234 & 0.0169 & 14.687 \\
\hline $1750-2050$ & $1 \cdot 10^{-5}$ & 0.0081 & 0.8222 & 5.2349 \\
\hline over/powyżej 2050 & $3 \cdot 10^{-5}$ & 0.0031 & 1.0981 & 1.8143 \\
\hline
\end{tabular}


As far as the recording accuracy of the engine states is concerned, one of the more impactful factors is the selection of the time of averaging of the measured quantities. We may assume that the more static the engine operation the longer the averaging time of the measured quantities may be. The specific operating conditions of tractor engines i.e. performing at quasi static engine speed allows an extension of the averaging time as opposed to road vehicles where accelerations and decelerations in engine speed are even more frequent. Based on the tests on a chassis dynamometer it has been ascertained that the optimum averaging time of the measured quantities for the tested tractor U912 amounts to 30 seconds. At shorter averaging time the measured quantities were too erratic due to accuracy issues. Too long an averaging time did not allow for all the changes in engine load.

The TRS system does not require any attention from the vehicle user. It operates independently from the driver. The recording module activates automatically upon engine start and deactivates upon engine stop. The data registration is performed on an exchangeable data carrier. A memory card fitted in the recording device enables the registration of the data. It is also possible to transmit data in real time to a desktop computer from more than one TRS device simultaneously through ground GPRS (General Packet Radio Service) transmitters, which is important for large area farms. In such a case additional software and a mainframe computer active on a continuous basis are required. The recording module is powered from the vehicle battery system and additionally fitted with a standalone battery. The recording module supports a variety of engine speed sensors using the Hall effect for the pulse generation from the teeth of the flywheel. In the recording module we can pre-set a number of pulses i.e. the number of teeth in the flywheel that equal to a single crankshaft revolution. This enables TRS to be applied in many types of engines irrespective of their size or power rating. The presetting of the fuel consumption module is performed in a similar manner. After entering the number of pulses into the memory of the recording module that equals a given unit of delivered fuel we can calculate the consumption through a wide range of metering devices. After the preliminary trials on a chassis dynamometer a prototype of a TRS was tested under operating conditions on a tractor U912 in one of the farms in the region of Pomorze Zachodnie. After a year of the tractor operation a TD characteristic for this engine was generated.

\section{Results of the measurements}

Generating of the TD characteristics gives a full spectrum of the engine loads under operation (Fig. 2). The longer the time of recording the thicker the density of the grid $\Delta \mathrm{M}_{\mathrm{o}}$ $\Delta \mathrm{n}_{\mathrm{s}}$, which allows a considerable graph filling [8]. The values of probability of occurrence of particular engine states in individual load ranges have been shown in Table 2 assuming the intervals of $\Delta \mathrm{M}$ equaling $20 \mathrm{~N} \cdot \mathrm{m}$, and the intervals of $\Delta \mathrm{n}_{\mathrm{s}}$ equaling $200 \mathrm{rpm}$.

From the obtained TD characteristics it results that the engine of the tested tractor most frequently operated at idle w skrajnych polach charakterystyki uniwersalnej może dochodzić do kilkunastu procent.

Wyznaczone wartości współczynników a, b, c, d dla zakresów prędkości obrotowych wału korbowego silnika Z8401.12 przedstawiono w tab. 1 .

W opracowanej metodzie sporządzania charakterystyki TD wielkości mierzone zliczane i rejestrowane są w stałych odstępach czasu. Następnie, zliczone w ten sposób wielkości, są uśredniane dla każdego przedziału czasowego. Jest to bardziej dokładna metoda w porównaniu z metodą opartą na tzw. próbkowaniu wielkości chwilowych. Pomiary wielkości chwilowych, np. przepływu paliwa, wymagają zastosowania urządzeń o bardzo dużej dokładności pomiaru, a przez to i droższych.

Jednym z czynników wpływających na dokładność rejestracji stanów pracy silnika jest dobór czasu uśredniania mierzonych wielkości. Można przyjąć założenie, że im bardziej charakter pracy silnika odpowiada stanom statycznym, tym czas uśredniania mierzonych wielkości może być dłuższy. Specyfika pracy silników ciągnikowych, tj. wykonywanie większości zabiegów agrotechnicznych przy quasi-statycznej prędkości obrotowej wału korbowego silnika, pozwala na wydłużenie czasu uśredniania w stosunku do pojazdów drogowych, w których występowanie przyspieszeń i opóźnień w ruchu obrotowym silnika jest częstsze. Na podstawie prób wykonanych na hamowni silnikowej ustalono, że optymalny czas uśredniania wielkości mierzonych dla badanego ciągnika U912 wynosi 30 s. Przy krótszym czasie uśredniania wielkości mierzone były obarczone zbyt dużym błędem wynikającym z dokładności przyrządów. Z kolei za długi czas uśredniania nie pozwolił na uwzględnienie wszystkich zmian obciążenia silnika.

System TRS nie wymaga obsługi ze strony użytkownika pojazdu. Działa niezależnie od kierowcy ciagnika. Moduł rejestratora aktywuje się samoczynnie po uruchomieniu silnika i wyłącza natychmiast po jego zatrzymaniu. Zapis danych odbywa się na wymiennym nośniku. Karta pamięci zainstalowana $\mathrm{w}$ rejestratorze umożliwia zapis danych. Istnieje również możliwość przesyłania danych w czasie rzeczywistym do komputera stacjonarnego $\mathrm{z}$ więcej niż jednego urządzenia TRS jednocześnie za pomocą naziemnych urządzeń nadawczych GPRS (General Packet Radio Service), co ma istotne znaczenie w przypadku gospodarstw wielkoobszarowych. Wymagane jest wtedy dodatkowe oprogramowanie oraz stale włączony komputer bazowy. Moduł rejestratora jest zasilany ze źródła prądu w pojeździe (akumulatora) oraz dodatkowo wyposażony w akumulator wewnętrzny. Moduł rejestratora może współdziałać z różnymi czujnikami prędkości obrotowej wykorzystującymi efekt Halla do generowania impulsów obrotowych, pochodzących od zębów wieńca koła zamachowego. W module rejestratora można zaprogramować liczbę impulsów, tj. zębów wieńca koła zamachowego, odpowiadających jednemu pełnemu obrotowi wału korbowego. Umożliwia to zastosowanie układu TRS do różnych typów silników niezależnie od ich wielkości czy też mocy. Podobnie możliwe jest także zaprogramowanie układu do pomiaru ilości zużywanego paliwa. 


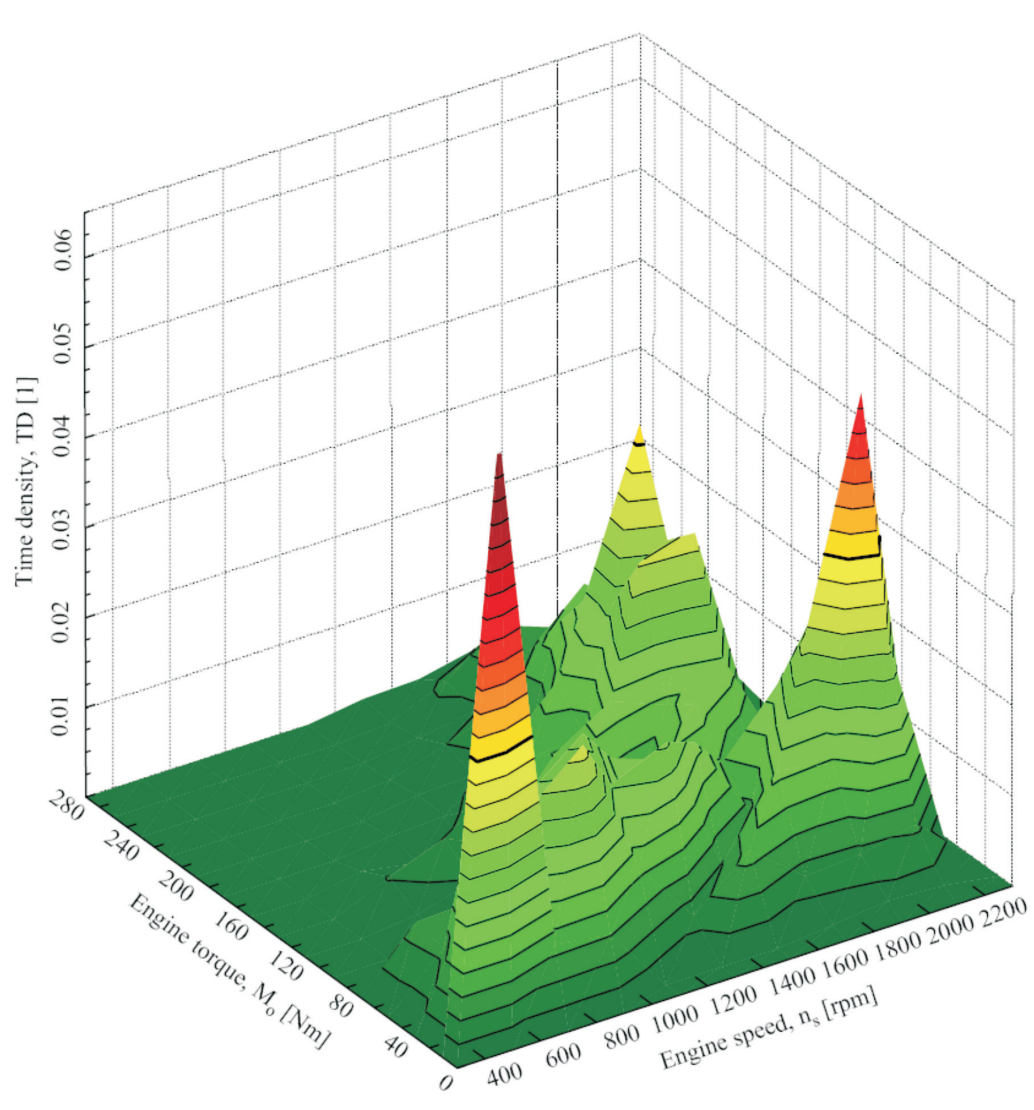

Fig. 2. TD characteristics of the tested engine

Rys. 2. Charakterystyka gęstości czasowej badanego silnika

Po wprowadzeniu do pamięci modułu rejestratora liczby impulsów przypadających na jednostkę objętości paliwa możliwy jest pomiar jego zużycia w szerokim zakresie rodzajów stosowanych miernic. Po wykonaniu wstępnych prób i ustawień regulacyjnych w hamowni silnikowej, prototyp TRS testowany był w warunkach eksploatacyjnych na ciagniku U912 w jednym z gospodarstw regionu Pomorza Zachodniego. Po rocznym okresie eksploatacji ciągnika otrzymano charakterystykę TD jego silnika.

\section{Wyniki pomiarów}

Sporządzenie charakterystyki TD daje pełen obraz obciążeń silnika występujących w eksploatacji (rys. 2). Im dłuższy jest czas rejestracji, tym większa może być gęstość siatki $\Delta \mathrm{M}_{\mathrm{o}}-\Delta \mathrm{n}_{\mathrm{s}}$, co pozwala na duże wypełnienie wykresu [8]. Wartości prawdopodobieństwa wystąpienia poszczególnych stanów pracy silnika w poszczególnych zakresach obciążeń przedstawiono w tab. 2 , przyjmując przedziały $\Delta \mathrm{M}_{\mathrm{o}}$ równe 20 $\mathrm{N} \cdot \mathrm{m}$, natomiast przedziały $\Delta \mathrm{n}_{\mathrm{s}}$ równe $200 \mathrm{obr} / \mathrm{min}$.

Z otrzymanej charakterystyki TD wynika, że silnik badanego ciąnika najczęściej pracował na biegu jałowym, tj. w

speed i.e. within the torque range of $0-20 \mathrm{~N} \cdot \mathrm{m}$ and engine speed of 400-600 rpm. The second most prevalent engine state was $60-80 \mathrm{~N} \cdot \mathrm{m}$ at 2000-2200 rpm. The load distribution obtained in the tests indicates an incomplete exploitation zakresie momentu obrotowego 0-20 N·m, przy prędkości obrotowej wału korbowego silnika w zakresie 400-600 obr/min. Drugim co do długości był stan pracy silnika

Table 2. Share of individual engine states (Z8401.12)

Tabela 2. Udziały poszczególnych stanów pracy silnika Z8401.12

\begin{tabular}{|c|c|c|c|c|c|c|c|c|c|}
\hline $\begin{array}{c}\text { Time Density,TD/ } \\
\text { Gestość czasowa [1] }\end{array}$ & \multicolumn{7}{|c|}{ Engine speed, $n_{s}$ [rpm]/Prędkość obrotowa wału korbowego silnika [obr/min] } \\
\hline $\begin{array}{c}\text { Engine torque/Moment } \\
\text { obrotowy silnika } \mathrm{M}_{\mathrm{o}}[\mathrm{N} \cdot \mathrm{m}]\end{array}$ & $\begin{array}{c}400 \\
-600\end{array}$ & $\begin{array}{c}600 \\
-800\end{array}$ & $\begin{array}{c}800 \\
-1000\end{array}$ & $\begin{array}{c}1000 \\
-1200\end{array}$ & $\begin{array}{c}1200 \\
-1400\end{array}$ & $\begin{array}{c}1400 \\
-1600\end{array}$ & $\begin{array}{c}1600 \\
-1800\end{array}$ & $\begin{array}{c}1800 \\
-2000\end{array}$ & $\begin{array}{c}2000 \\
-2200\end{array}$ \\
\hline $0-20$ & $\mathbf{0 . 0 6 7 2 7}$ & 0.00859 & 0.00761 & 0 & 0 & 0 & 0.00062 & 0.00132 & 0.00097 \\
\hline $20-40$ & 0.01381 & 0.02107 & 0.02647 & 0.01080 & 0.00345 & 0.00867 & 0.00380 & 0.00424 & 0.00557 \\
\hline $40-60$ & 0.00575 & 0.03160 & 0.00744 & 0.01779 & 0.02044 & 0.00486 & 0.01336 & 0.01212 & 0.02345 \\
\hline $60-80$ & 0.00637 & 0.00664 & 0.01646 & 0.02124 & 0.01097 & 0.01628 & 0.00672 & 0.02407 & $\mathbf{0 . 0 4 9 0 3}$ \\
\hline $80-100$ & 0 & 0.00115 & 0.00717 & 0.01186 & 0.01420 & 0.01212 & 0.00955 & 0.01646 & 0.02655 \\
\hline $100-120$ & 0 & 0.00071 & 0.00239 & 0.00991 & 0.01115 & 0.00761 & 0.01407 & 0.00708 & 0.01442 \\
\hline $120-140$ & 0 & 0.00266 & 0.00496 & 0.00221 & 0.01044 & 0.01416 & 0.01177 & 0.01495 & 0.00327 \\
\hline $140-160$ & 0 & 0.00106 & 0 & 0.00389 & 0.00743 & 0.00832 & 0.02531 & 0.02664 & 0.00433 \\
\hline $160-180$ & 0 & 0 & 0.00071 & 0.00097 & 0.00566 & 0.01177 & 0.01814 & 0.02363 & 0.00805 \\
\hline $180-200$ & 0 & 0 & 0.00018 & 0.00106 & 0.00132 & 0.00362 & 0.01672 & 0.03434 & 0.00194 \\
\hline $200-220$ & 0 & 0 & 0 & 0.00053 & 0.00247 & 0.00478 & 0.01177 & 0.01292 & 0.00424 \\
\hline $220-240$ & 0 & 0 & 0 & 0.00017 & 0.00097 & 0.00194 & 0.00655 & 0.01212 & 0.00053 \\
\hline $240-260$ & 0 & 0 & 0 & 0 & 0.00044 & 0.00309 & 0.00725 & 0.00504 & 0.00053 \\
\hline $260-280$ & 0 & 0 & 0 & 0 & 0.00088 & 0.00106 & 0.00239 & 0.00256 & 0 \\
\hline
\end{tabular}


of the power capacity of the tested tractor. Besides, the long time of the idle engine state indicates a considerable use of the engine to drive the tractor's peripheral equipment.

\section{Conclusions}

Contemporary measuring techniques have reduced the time consumption while performing the field tests, which is a reason for a more frequent use of the results of these tests in forecasting and modeling of the processes occurring during tractor operation. The development of the TRS system is an excellent example here, thanks to which the here presented TD characteristics of an engine in operation has been prepared.

The TRS system may be applied in the following fields:

a) recording of the tractor's time of operation and fuel consumption,

b) determining of the technical condition of the tractor based on variations in fuel consumption at identical operations or comparison of several units,

c) planning of trajectories in field works preventing multiple soil tamping,

d) determining of the extent of power exploitation,

e) optimization of the tractor's operation through appropriate selection of working speeds thanks to visualizations and signaling of the measured quantities in the driver's compartment,

f) determining of the exhaust emissions from agricultural tractors based on the fuel consumption in the function of power (simulation tests as per European Standards).

Artykut recenzowany. obciążonego odpowiednio 60-80 N·m przy 2000-2200 obr/min. Uzyskany w badaniach rozkład obciążeń świadczy o niepełnym wykorzystaniu mocy ciagnika. Ponadto długi czas pracy silnika na biegu jałowym wskazuje na istotny udział czynności pomocniczych, tj. agregatownie sprzętu itp.

\section{Podsumowanie}

Obecna technika pomiarowa pozwala na obniżenie pracochłonności wykonywania badań polowych, co sprawia, że ich wyniki są coraz częściej wykorzystywane do prognozowania oraz modelowania procesów zachodzących podczas eksploatacji ciagnika. Przykładem tego typu działań jest stworzenie systemu TRS, dzięki któremu wykonano przedstawioną w artykule charakterystykę TD badanego silnika w warunkach eksploatacyjnych.

System TRS może znaleźć praktyczne zastosowanie w następujących obszarach:

a) ewidencjonowania czasu pracy ciągnika oraz zużycia paliw płynnych,

b) określania stanu technicznego ciagnika na podstawie zmian zużycia paliwa przy takich samych zabiegach agrotechnicznych lub przez porównanie kilku ciągników,

c) planowania przejazdów (ścieżek technologicznych) w uprawach polowych pozwalających uniknąć wielokrotnego ugniatania gleby,

d) określania stopnia wykorzystania mocy ciągnika w gospodarstwie,

e) optymalizacji pracy ciagnika przez odpowiedni wybór przełożeń dzięki wizualizacji i sygnalizacji mierzonych wielkości w kabinie operatora,

f) określenia emisji szkodliwych składników spalin z ciągników rolniczych na podstawie przebiegowego zużycia paliwa w funkcji rozwijanej mocy (testy symulacyjne według normy europejskiej).

\section{Bibliography/Literatura}

[1] Chłopek Z.: Modelowanie procesów emisji spalin w warunkach eksploatacji trakcyjnej silników spalinowych. Prace Naukowe Politechniki Warszawskiej, z. 173, 1999.

[2] Cichy M.: Nowe teoretyczne ujęcie charakterystyki gęstości czasowej. Silniki Spalinowe 2-3, 1986, s. 75-78.

[3] de Souza E.G., Milanez L.F.: Indirect Evaluation of the Torque of Diesel Engines. Transactions of the ASAE 5 (31), 1988, s. $1350-1354$.

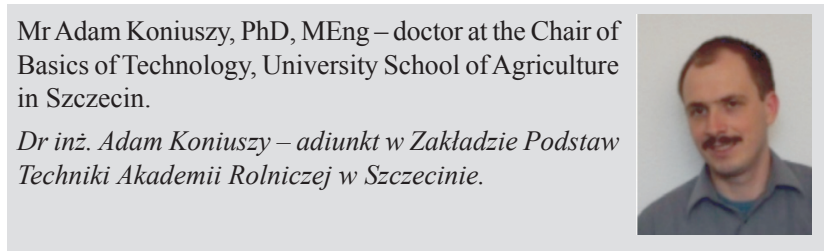

[4] Harris H.D.: Prediction of the Torque and Optimum Operating Point of Diesel Engines using Engine Speed and Fuel Consumption. Journal Agricultural Engineering Research 53, 1992, s. 93-101.

[5] Kim J.H., Kim K.U., Wu Y.G.: Analysis of transmission load of agricultural tractors Journal of Terramechanics 37, 2000, s. $113-125$.

[6] Koniuszy A., Nadolny R.: Sposób monitoringu pracy ciagnika oraz urządzenie do jego realizacji. Zgłoszenie patentowe P 381892, 2007.

[7] Opuchlik A., Smela M.: Pomiar temperatury spalin oraz przesunięcia listwy zębatej pompy wtryskowej jako pośrednie metody wyznaczania momentu obrotowego silnika. Praca magisterska niepublikowana, AR Szczecin, 1992.

[8] Romaniszyn K.M.: Ocena różnic w określaniu zużycia paliwa samochodu na podstawie charakterystyki uniwersalnej i dynamicznej. Silniki Spalinowe 2 (119), 2004, s. 48-54. 